\title{
Perjanjian Pemegang Saham Dan Dampaknya Terhadap Pemangku Kepentingan lainnya Di Perusahaan
}

\author{
Jelly Nasseri \\ Program Magister Kenotariatan Universitas Jayabaya, Jakarta, Indonesia \\ jellynasseri@gmail.com
}

\author{
Received: 26 April 2021; Revised: 16 July 2021; Accepted: 13 August 2021 \\ DOI: http://dx.doi.org/10.37905/aksara.7.3.1017-1028.2021
}

\begin{abstract}
Abstrak
Secara umum, di dunia terdapat dua sistem pengurusan perusahaan yang menonjol, yaitu: sistem satu tingkat dan sistem dua tingkat, namun dalam kaitannya dengan hubungan sistem manajemen satu tingkat (one-tier) dan dua tingkat (two-tier), penerapan kedua sistem ini di semua negara hampir sama, yaitu adanya dua dewan - dewan komisaris dan dewan direksi pada sistem two-tier dan hanya satu dewan - dewan direksi pada sistem - one-tier. Dalam menjalankan aktivitas bisnis sehari-hari para pemegang saham perusahaan cenderung menjaga kepentingannya dalam hubungan antar pemegang saham. Meskipun hubungan antara pemegang saham telah diatur dalam berbagai peraturan perundang-undangan, dan juga diatur dalam anggaran dasar perusahaan, namun masih ada hal-hal penting yang perlu diatur secara tersendiri, diluar peraturan dan pasal-pasal akta pendirian dan anggaran dasar perusahaan, antara lain klausul right of first refusal yang memaksa pemegang saham yang ingin menjual sahamnya untuk terlebih dahulu menawarkan sahamnya kepada pemegang saham lain; pengalihan terbatas saham yang melarang pemegang saham untuk menjual sahamnya tanpa persetujuan semua pemegang saham; opsi untuk memanggil atau menempatkan sahamnya kepada mitranya; penyediaan kendali yang membutuhkan persetujuan dengan suara bulat untuk keputusan besar; dan klasulnon-persaingan yang melarang pemegang saham untuk bersaing dengan perusahaan. Para pemegang saham biasanya mengatur hubungan khusus mereka secara terpisah dalam perjanjian pemegang saham. Makalah ini membahas beberapa hal penting yang harus diperhatikan dalam penyusunan perjanjian pemegang saham dan dampaknya bagi pemangku kepentingan (stakeholder) lain di perusahaan. Penulis menemukan bahwa diperlukan adanya keterbukaan dalam penyusunan perjanjian pemegang saham agar tidak merugikan kepentingan pihak-pihak lain terutama stakeholder perusahaan lainnya.
\end{abstract}

Kata kunci: Perusahaan, Anggaran Dasar, Perjanjian, Pemegang Saham

\begin{abstract}
In general, there are two prominent corporate management systems in the world, namely: a one-tier system and a two-tier system, but in relation to the relationship between one-tier and two-tier management systems, the application of these two systems in all countries it is almost the same, namely there are two boards - a board of commissioners and a board of directors on a two-tier system and only one board - a board of directors on a one-tier system. In carrying out daily business activities, company shareholders tend to maintain their interest in the relationship between shareholders.Although the relationship between shareholders has been regulated in various laws and regulations, and is also regulated in the company's articles of association, there are still important matters that need to be regulated separately, apart from the regulations and articles of the deed of establishment and the company's articles of association, among others a right of first refusal that forces shareholders who wish to sell their shares to first offer their shares to other shareholders; a limited transfer of shares that prohibits shareholders from selling their shares without the approval of all shareholders; options to call or assign shares to partners; providing controls requiring unanimous approval of major decisions; and the non-competitive class that prohibits shareholders from competing with the company.The shareholders usually arrange their special relationship separately in the shareholder agreement. This paper discusses several important things that must be considered in the preparation of shareholder agreements and their impact on other stakeholders in the company. The author finds that there is a need for openness in the preparation of shareholder agreements so as not to harm the interests of other parties, especially other company stakeholders.
\end{abstract}

Key words:Company, Article of association, Shareholder, Agreement 


\section{PENDAHULUAN}

Di era globalisasi ini hampir semua negara memiliki peraturan perundangundangan sendiri tentang perusahaan, meskipun terdapat kecenderungan saling mempengaruhi diantara negara-negara yang maju dengan negara berkembang. Dalam bidang hukum perbandingan terdapat teori transplantasi hukum sebagai salah satu cara sistem hukum suatu negara mempengaruhi sistem hukum atau ketentuan hukum negara lain yaitu dengan cara transplantasi sistem hukum atau ketentuan hukum yang bersumber dari satu yurisdiksi negara ke negara lain atau dengan membawa ketentuan atau klausul dari negara lain untuk diterapkan atau dimasukkan kedalam undang-undang atau undangundang suatu negara, namun tidak ada satu hukum pun yang diakui oleh semua negara. (Alan Watson, 1974).

Setiap negara Habib Jouber (2021) memiliki hukum dan peraturan perusahaannya sendiri, yang berbeda dari satu negara ke negara lain. Meskipun di dunia terdapat dua sistem pengurus perusahaan yang menonjol, yaitu: system satu tingkat (one-tier) dan duatingkat (two-tier), namun dalam kaitannya dengan hubungan sistem manajemen, penerapan kedua sistem ini di semua negara tidak sama sebagai contoh, sistem hukum perusahaan Prancis membolehkan perusahaan untuk memilih apakah akan menggunakan sistem one-tier atau menggunakan sistem two-tier. (Benedicte Millet-Reyes, 2010). Penyebab penerapan system tersebut antara lain karena pengaruh sistem hukum common law dan sistem hukum civil law, dimana sebagian negara civil law mengadopsi system two-tier dan sebagian lainnya mengadopsi sistem one-tier. Di negara common law juga beberapa mengadopsi system one-tier dan beberapa mengadopsi system two-tier. (EcoDaa.s.b.l. 2014).

Struktur tata kelola dua tingkat berasal dari tradisi organisasi dasar Jerman, di mana rapat pemegang saham menunjuk dewan pengawas, yang kemudian menunjuk dewan manajemen. Sebaliknya, sistem satu tingkat diturunkan dari tradisi AngloAmerika. Dalam model tata kelola ini, rapat pemegang saham menunjuk dewan direksi yang kemudian menunjuk beberapa direktur sebagai komite pengendalian manajemen yang dipercayakan dengan fungsi pemantauan (Ghezzi, F., and Malberti, C. 2008).

Dalam hal ini Indonesia secara hukum adalah menganut sistem two-tier, sebagaimana dicantumkan di dalam Pasal 2.1 Undang-UndangNomor 40 Tahun 2007 Tentang Perseroan Terbatas (“UUPT/2007”):

"Organ Perseroan adalah Rapat Umum Pemegang Saham, Direksi, dan Dewan Komisaris".

Selanjutnya pada Pasal 1 angka 5 dan Pasal 1 angka 6 UUPT/2007 disebutkan pembagian tugas dan tanggung jawab diantara direksi dan dewan komisaris:

"Direksi adalah Organ Perseroan yang berwenang dan bertanggung jawab penuh atas pengurusan Perseroan untuk kepentingan Perseroan, sesuai dengan maksud dan tujuan Perseroan serta mewakili Perseroan, baik di dalam maupun di luar pengadilan sesuai dengan ketentuan anggaran dasar".

"Dewan Komisaris adalah Organ Perseroan yang bertugas melakukan pengawasan secara umum dan /atau khusus sesuai dengan anggaran dasar serta memberina sihatke pada Direksi”. 
Dalam hal kepemilikan perusahaan, negara-negara juga menganut sistem yang berbeda. Beberapa negara hanya mengakui satu jenis kepemilikan, yaitu kepemilikan saham, dan ada yang mengenal dua jenis, yaitu: anggota dan pemegang saham. Irlandia, misalnya, mengakui dua kepemilikan yang berbeda, yaitu: anggota dan pemegang saham. Anggota perusahaan adalah orang yang ikut serta dalam modal suatu perusahaan, terdaftar sepertii tu dan berhak atas hak-hak tertentu. Para penyusun awal anggaran dasar perusahaan dianggap telah setuju untuk menjadi 'anggota' perusahaan, dan pada pendaftarannya, namanya dicantumkan sebagai anggota dalam daftar anggota dan pemegang saham adalah orang yang memiliki saham atau saham di sebuah perusahaan. Ketika namanya dimasukkan kedalam daftar anggota, mereka menjadi anggota perusahaan. Hak dan tanggung jawab keanggotaan bervariasi tergantung pada sifat perusahaan. Namun, perlu dicatat bahwa seseorang yang membeli saham di suatu perusahaan, sementara menjadi pemegang saham sejak tanggal pembelian, tidak akan menjadi anggota perusahaan sebelum namanya dimasukkan kedalam daftar anggota perusahaan. (Office of the Director of Corporate Enforcement (2015).

Semua sistem hukum perusahaan mengenal satu jenis hubungan pemangku kepentingan yang sama, yaitu hubungan antara perusahaan dan kreditornya. Hal itu adalah karena hubungan perusahaan / kreditor sangat dipengaruhi oleh satu fitur universal dari undang-undang tentang perusahaan lintas yurisdiksi, yaitu, prinsip tanggung jawab terbatas bagi pemegang saham perusahaan, setidaknya sebagai aturan dasar. (Paul L Davies (2000).

Saat ini perusahaan tidak dapat lagi hanya berfokus pada pendapatan dan keuntungan, yaitu untuk memberikan keuntungan bagi pemilik perusahaan, dalam hal ini para pemegang saham, melainkan harus pula memperhatikan kepentingan stake holders lainnya, karena dari perspektif teori stakeholder, nilai ekonomi dari suatu perusahaan diciptakan oleh hubungan sukarela di antara banyak pihak yang bekerja sama untuk menciptakan bisnis yang sukses. Hal itu merupakan teori etika tentang nilai-nilai manajemen dalam hubungan dengan pihak-pihak tersebut, dan juga merupakan teori manajemen tentang bagaimana menciptakan dan mengelola perusahaan yang sukses (Cynthia A. Williams (2016). Oleh karena itu, perusahaan harus menyesuaikan tujuannya dari pendapatan dan keuntungan yang berorientasi pada kepentingan pemangku kepentingan yang lebih luas agar dapat mempertahankan eksistensinya di pasar. Namun, meski ada perubahan tujuan perusahaan yang lebih mementingkan seluruh stakeholders, pencarian pendapatan dan keuntungan tetap menjadi tujuan penting semua perusahaan. Pemegang saham perusahaan tetap memberikan kekuasaan kepada direksi perusahaan untuk bekerja dengan tujuan mencari pendapatan dan laba.

Dalam menjalankan aktivitas bisnis sehari-hari para pemegang saham perusahaan cenderung menjaga kepentingannya dalam hubungan antar pemegang saham. Meskipun hubungan antara pemegang saham telah diatur dalam berbagai peraturan perundang-undangan mengenai perusahaan dan pengurus perusahaan, dan juga diatur dalam anggaran dasar perusahaan, namun masih terdapat beberapa hal penting bagi pemegang saham yang perlu diatur secara individual tersendiri, di luar hukum dan peraturan dan pasal-pasal akta pendirian dan anggaran dasar perusahaan. 
Para pemegang saham biasanya mengatur hubungan khusus mereka secara terpisah dalam perjanjian pemegang saham.

\section{PEMBAHASAN}

\subsection{Akta Pendirian dan Anggaran Dasar Perusahaan}

Di dalam Pasal 8 ayat (1) UUPT/2007 disebutkan ketentuan bahwa Akta Pendirian memuat anggaran dasar dan keterangan lain berkaitan dengan pendirian perseroan. Dengan ketentuan tersebut, secara umum diketahui bahwa suatu perseroan terbatas selain harus mematuhi undang-undang yang mengatur tentang perseroan terbatas juga harus tunduk pada anggaran dasar Perseroan yang sudah ditetapkan.

Selanjutnya di dalam Pasal 15 UUPT/2007 disebutkan pula bahwa halhal yang dimuat di dalam Anggaran Dasar adalah :

1. Nama dan tempat kedudukan Perseroan;

2. Maksud dan tujuan serta kegiatan usaha Perseroan;

3. Jangka waktu berdirinya Perseroan;

4. Besarnya jumlah modal dasar, modal ditempatkan, dan modal disetor;

5. Jumlah saham, klasifikasi saham apabila ada berikut jumlah saham untuk tiap klasifikasi, hak-hak yang melekat pada setiap saham, dan nilai nominal setiap saham;

6. Nama jabatan dan jumlah anggota Direksi dan Dewan Komisaris;

7. Penetapan tempat dan tata cara penyelenggaraan RUPS;

8. Tata cara pengangkatan, penggantian, pemberhentian anggota Direksi dan Dewan Komisaris;

9. Tata cara penggunaan laba dan pembagian dividen.

Ketentuan yang terdapat di dalam akta pendirian dan anggaran dasar perusahaan adalah merupakan perjanjian di antara para pemegang saham. Hal itu sesuai dengan ketentuan Pasal 7 ayat (1) UUPT/2007 bahwa suatu perseroan terbatas didirikan oleh dua orang atau lebih dengan akta notaris dalam bahasa Indonesia, yang diperjelas dengan Pasal 1 angka 1 UUPT/2007 bahwa perseroan terbatas didirikan berdasarkan perjanjian. Oleh karena pendirian perseroan terbatas dibuat berdasarkan perjanjian, maka dengan sendirinya semua unsur perjanjian dan syarat sahnya sebagaimana diatur di dalam Buku III KUHPerdata, harus pula dipenuhi, dengan pengecualian sebagaimana ditentukan di dalam Pasal 7 ayat (7) UUPT/2007. (Herlin Budiono (2012).

Pada umumnya, (Suwarsono Muhammad dan Andi Yuliansyah, 2008) semua hak dan tanggung jawab pemegang saham tercantum dalam anggaran dasar perusahaan, seperti dapat dilihat pada ketentuan Pasal 15 UUPT /2007 diatas. Namun, sebuah perusahaan tidak beroperasi dalam lingkungan yang terisolasi, perusahaan harus bergerak dinamis dan harus bereaksi terhadap lingkungan yang sangat kompleks yang selalu berubah dan bergerak. Untuk itu, para pemegang saham harus dapat melindungi kepentingannya apabila terjadi perubahan lingkungan dimana perusahaan beroperasi. Meski tidak mungkin untuk meramalkan apa yang terjadi di masa yang akan datang, namun para pemegang saham umumnya melakukan antisipasi, terhadap perubahan lingkungan bisnisnya. 
Di samping itu, Bayu Wirawan (2014) di Indonesia masih banyak perusahaan yang berupa perusahaan milik keluarga. Di berbagai perusahaan seperti ini, permasalahan yang sering timbul bukan hanya antara pemilik dan manajemen, melainkan juga di antara pemegang saham minoritas dengan pemilik saham keluarga, termasuk manajemen yang berasal dari keluarga. Pemegang saham mayoritas, dalam hal ini keluarga, memiliki kecenderungan untuk mempertahankan dominasinya di dalam perusahaan, melalui manajemennya dan juga pembatasan praktik pengelolaan perusahaan yang baik.

Dalam rangka melindungi kepentingannya, karena pada kenyataannya pasalpasal anggaran dasar yang berisi ketentuan standar tidak dapat menampung semua hak dan kewajiban pemegang saham, terutama hak dan tanggung jawab yang diinginkan secara khusus oleh para pemegang saham, maka untuk itu para pemegang saham berupaya menjaga kepentingannya dengan mengadakan perjanjian pemegang saham.

\subsection{Perjanjian Pemegang Saham}

Hukum perusahaan pada dasarnya membahas tiga rangkaian masalah pokok yang melekat dalam struktur perusahaan besar, yaitu: masalah yang timbul antara manajemen dan pemegang saham sebagai satu kelas; antara pemegang saham mayoritas dan pemegang saham minoritas; dan antara pengendali perusahaan (apakah manajer atau pemegang saham mayoritas) dan pemangku kepentingan non-pemegang saham. Namun undang-undang perusahaan tidak cukup untuk memenuhi kebutuhan pemegang saham dalam kaitannya dengan kekuasaan untuk mengendalikan bisnis perusahaan. Karena tidak cukupnya anggaran dasar dan undang-undang tentang perusahaan dalam menampung semua kepentingan para pemegang saham, maka dalam praktek diperlukan adanya perjanjian pemegang saham, yang dibuat diantara semua pemegang saham, biasanya diantara pemegang saham pendiri perusahaan.

Alasan lainnya adalah karena pemegang saham tidak terlibat secara langsung dalam pengambilan keputusan penting dan tidak terlibat dalam pengelolaan harian operasional perusahaan, oleh karena itu timbul kebutuhan bagi mereka untuk membuat suatu struktur yang dapat melindungi investasi mereka sekaligus memastikan bahwa mereka memperoleh pengembalian modal yang mereka miliki yang dimasukkan ke dalam operasional perusahaan. (TareqNa'el Al-Tawil (2018). Ini terutama mengingat bahwa kebanyakan undang-undang tentang penanaman modal mengamanatkan bahwa setiap perusahaan terbatas yang didirikan harus memiliki satu atau lebih pemegang saham domestik yang kepemilikannya sama atau lebih dari 51 persen. Ini menyiratkan bahwa, terlepas dari persentase investasi mereka, investor asing dibatasi pada kepemilikan maksimum 49 persen dari perusahaan mana pun yang didirikan. Oleh karena itu, perjanjian pemegang saham sangat penting dalam hal ini. Seperti yang disampaikan di atas, perjanjian pemegang saham dapat secara khusus membantu pemegang saham minoritas untuk tidak hanya mengandalkan anggaran dasar perusahaan, yang dibatasi untuk melindungi kepentingan pihak-pihak mayoritas dalam menunjuk direktur dan manajer, memveto keputusan, dan dalam pembagian laba.

Perjanjian pemegang saham Crawford, W. W., \&Gratias, P. P. (1983) adalah dokumen hukum yang mengatur hubungan antara beberapa atau semua pemegang 
saham dari perusahaan yang dimiliki. Tujuan utama pada umumnya adalah: (1) untuk mengatur keadaan di mana hubungan antara pemegang saham itu sendiri dan antara pemegang saham dan korporasi akan dihentikan dan (2) untuk menjelaskan hak dan kewajiban pemegang saham sehubungan dengan disposisi dan akuisisi saham pemegang saham yang keluar dari perusahaan. Perjanjian pemegang saham dapat mengalokasikan di antara hak pemegang saham tertentu untuk menunjuk individu yang akan menjabat dalam dewan direksi perusahaan, memberikan hak suara khusus kepada pemegang saham tertentu, memastikan bahwa pemegang saham tertentu memiliki hak memesan efek terlebih dahulu jika perusahaan menerbitkan efekekuitas tambahan, dan / atau memberikan hak untuk membatasi atau ikut serta dalam pengalihan saham oleh pemegang saham lain, dan berbagai hal lainnya (The Corporation Law Committee of the Association of the Bar of the City of New York (2010).

Klausul paling relevan yang sering dimasukkan dalam perjanjian adalah sebagai berikut: Pemungutan suara. Para pihak berkomitmen untuk bertemu sebelum rapat pemegang saham dan untuk mencapai keputusan yang mengikat tentang cara menggunakan hak suara mereka. Konsultasi. Para pihak berkomitmen untuk saling bertukar pikiran, untuk kemungkinan mencapai cara pemungutan suara yang sama dalam rapat pemegang saham, tetapi mereka tidak berkomitmen untuk mencapai keputusan yang mengikat. Komposisi dewan. Para pihak menyepakati komposisi dewan direksi. Lebih spesifiknya, setiap pihak diberi hak untuk menunjuk sejumlah direktur. Pembatasan transfer saham. Perdagangan saham para pihak yang terlibat dalam perjanjian dibatasi. Seringkali hak preemption diberikan kepada para pihak (Angelo Baglioni (2011)..

Secara umum, dapat dikatakan bahwa perjanjian pemegang saham biasanya berisi klausul yang menetapkan hak dan kewajiban di antara pemegang saham sebagai berikut : right of first refusal yang memaksa pemegang saham yang ingin menjual sahamnya kepada pihak ketiga untuk terlebih dahulu menawarkan sahamnya kepada pihak pemegang saham lain; pengalihan terbatas saham yang melarang pemegang saham untuk menjual sahamnya tanpa persetujuan semua pemegang saham; opsi untuk memanggil atau menempatkan sahamnya kepada mitranya; penyediaan kendali yang membutuhkan persetujuan dengan suara bulat untuk keputusan besar; dan klasul non-persaingan yang melarang pemegang saham untuk bersaing dengan perusahaan. (Andre CARVALHAL (2012).

Perjanjian pemegang saham juga dapat menetapkan kebijakan tentang dividen, bonus, dan gaji dan, jika ada karyawan pemegang saham minoritas, itu harus mencakup banyak poin yang biasanya ditemukan dalam kontrak kerja atau perjanjian kemitraan. Lebih khusus lagi, hak tersebut harus dijabarkan secara rinci dan kewajiban pemegang saham berkelanjutan untuk membeli saham milik pemegang saham yang akan keluar bersama dengan mekanisme untuk mendanai hak atau kewajiban mereka. Hal ini memberikan pemegang saham yang keluar dengan pasar untuk sahamnya dan pemegang saham yang melanjutkan hak untuk memilih pemegang saham penggantinya.

Perjanjian pemegang saham juga dapat digunakan untuk membuat cara damai dalam menyelesaikan setiap perselisihan yang mungkin muncul di antara pemegang saham perusahaan. Tujuan akhirnya adalah untuk melindungi hak dan kepentingan 
komersial pemegang saham. Sebagai kontrak, kesepakatan pemegang saham diatur oleh aturan hokum kontrak. Oleh karena itu, perjanjian pemegang saham ini berbeda dari anggaran dasar perusahaan, yang secara signifikan diatur oleh Undang-Undang Perusahaan.

Pada umumnya perjanjian pemegang saham dibuat pada awal pendirian perusahaan, namun belakangan ini sering pula setelah saham ditransfer dengan satu atau lain cara, barulah pemilik asli dan pemilik baru membuat perjanjian pemegang saham. Persetujuan yang dibuat mencakup ketentuan dasar, yang membatasi kepemilikan dan tindakan pemegang saham. Misalnya, bahwa saham tidak dapat dialihkan ke pihak lain tanpa hak penolakan (right of first refusal) untuk kepentingan pemegang saham lainnya yang sudah ada. (Dennis C. Reardon (2019).

Namun, dalam hal ini terjadi perdebatan apakah perjanjian pemegang saham dibenarkan secara hukum. Ada pendapat yang menyatakan bahwa perjanjian pemegang saham tersebut jelas cacat secara hukum, karena hal itu memungkinkan penggunaan perjanjian pribadi untuk menghindari ketentuan hukum perusahaan. Ini menimbulkan pertanyaan prinsip yang cukup mendasar yaitu: adanya konflik antara kebebasan berkontrak diantara pemegang saham dan keutamaan aturan hukum yang wajib ditaati. Dengan latar belakang ini, tidak mengherankan bahwa pengadilan Inggris telah menghasilkan putusan terhadap kasus hukum yang tidak konsisten.

Perjanjian pemegang saham sering pula dibuat untuk perihal yang lainnya, sebagai contoh, praktek di yang terjadi di Inggris dan Hong Kong. Meskipun hukum Inggris dan Hong Kong memberikan hak hukum kepada anggota perusahaan untuk mencari penyelesaian melalui gugatan ke pengadilan mengenai hal-hal seperti pembubaran perusahaan, namun perjanjian tersendiri dapat pula digunakan untuk melakukan pembatasan pada pelaksanaan ketentuan hukum tersebut. Pembatasan semacam itu dapat terjadi dalam dua bentuk, yaitu dengan perjanjian biasa dan dalam perjanjian pemegang saham. Pencantuman dalam perjanjian pemegang saham dilakukan dengan penggabungan klausula arbitrase dalam perjanjian di mana para pihak setuju untuk menyerahkan sengketa mereka kearbitrase di luar pengadilan. (Rita Cheung (2012). Meskipun pengadilan Inggris masih jauh dari suara bulat dalam menerima prinsip-prinsip yang diakui di dalam kasus yang pernah diputuskan, pihak pengadilan menunjuk kantren peningkatan kebebasan untuk kontrak priba di pemegang saham.

Di masa lalu, pengadilan di Amerika Serikat tidak menyambut baik perjanjian pemegan saham. Di zaman dimana undang-undang dan aturan hukum umum yang berfokus pada perusahaan dengan operasional publik, hakim menunjukkan rasa tidak setuju yang cukup besar terhadap perusahaan tertutup dan perjanjian pemegang saham, dan perjanjian pemegang saham dianggap tidak dapat dilaksanakan karena bertentangan dengan kebijakan publik. Karena perusahaan tertutup menjadi jenis asosiasi bisnis yang lebih sering digunakan, pengadilan di Amerika Serikat mulai mengevaluasi kembali posisi mereka terhadap perjanjian pemegang saham. Sebagian besar negara bagian telah memberlakukan undang-undang khusus tentang perjanjian pemegang saham. (Rainer Kulms (2001). Sebagai untuk teknik legislatif, beberapa negara bagian meletakkan aturan-aturan dasar untuk perwakilan dalam pemungutan suara dan memberikan pengecualian untuk perjanjian pemungutan suara pemegang saham. 
Di Brasil, Undang-UndangNomor 6.404/76, disebut sebagai Hukum Perusahaan Brasil, mengadopsi peristiwa yang menghebohkan dalam penyelesaian kasus Perjanjian Pemegang Saham, Undang-Undang ini adalah salah satu yang pertama kali berkaitan dengan penanganan secara langsung masalah tersebut. Tujuan utamanya adalah untuk menghindari ekses yang terjadia kibat penggunaan perjanjian pemegang saham tersebut. (Silva, Andre Leonardo Pruner da; Lana, Jeferson; Marcon, Rosilene Agreeing and Impacting, 2018).

Di Italia, perjanjian pemegang saham semakin populer. Antara tahun 1990 dan 2006, telah banyak perusahaan yang dikendalikan melalui kesepakatan tersebut, total perusahaan yang terdaftar telah meningkat dari $18 \%$ menjadi $22 \%$ pada nilainya, dan dari 5\% hingga 11\% dalam jumlahnya menurut laporan Bank of Italy tahun 2007.

Di Indonesia tidak terdapat ketentuan tentang perjanjian pemegang saham, baik di dalam UUPT/2007 maupun di dalam peraturan-peraturan pelaksanaannya. Namun, dalam praktek telah banyak perusahaan yang mengadakan perjanjian pemegang saham. Perusahaan yang mengadakan perjanjian pemegang saham berpegang kepada azas kebebasan berkontrak yang diakui menurut hukum perjanjian Indonesia. Namun belum ditemukan putusan pengadilan mengenai perjanjian pemegang saham.

\subsection{Dampak Perjanjian Pemegang Saham Terhadap Stakeholder Lainnya}

Ekonomi dan pelaku bidang keuangan secara tradisional berpendapat bahwa tujuan utama perusahaan adalah memaksimalkan kekayaan pemegang saham. Hal itu dikritik oleh pihak yang berpendapat bahwa kinerja perusahaan tidak boleh dinilai terlalu sempit dengan hanya berfokus pada nilai kekayaan perusahaan. Tetapi juga bahwa perusahaan memiliki tanggung jawab yang luas tidak hanya kepada pemegang saham tetapi juga kepada pemangku kepentingan lainnya. (Abrahim Soleimani, William D. Schneper and William Newburry (2014).

Dalam melaksanakan kegiatan operasionalnya, pengelola perusahaan harus senantiasa memperhatikan kepentingan pemegang saham dan pemangku kepentingan lainnya berdasarkan asas kesetaraan dan kewajaran. Berdasarkan teori stakeholder, perusahaan tidak boleh mengabaikan kepentingan para pemangku kepentingan karena keterlibatan mereka dengan, dan dalam perusahaan merupakan bagian penting dari sebuah perusahaan yang berhasil dalam jangka panjang. Perusahaan tidak dapat berfungsi dengan baik tanpa kontribusi dari pemangku kepentingan. Sebagai contoh, perusahaan tidak akan berhasil jika pekerjanya tidak puas dan bahkan melakukan aksi protes, atau pelanggan yang ada dan/atau yang potensial kecewa dengan produk perusahaan. Gagasan bahwa perusahaan harus memperhatikan para pemangku kepentingan bukanlah hal baru, banyak pendukung keunggulan pemegang saham telah lama berpandangan bahwa kepentingan pemangku kepentingan lainnya harus dipertimbangkan dan dipenuhi. (Andrew Keay (2019).

Secara umum, perjanjian pemegang saham memuat hubungan individual antara pemegang saham sebagai pihak yang terikat kontrak dan tidak terbuka untuk umum, sedangkan anggaran dasar adalah terbuka untuk pemeriksaan publik di pencatatan perusahaan, dan di negara yang tidak memiliki pencatatan perusahaan maka harus mengungkapkan kepada publik sesuai dengan hukum perusahaan yang berlaku. Sebagai perjanjian individual antara pemegang saham sebagai pihak dalam 
perjanjian, maka perjanjian pemegang saham itu tidak mengikat pemegang saham lain yang bukan merupakan pihak, namun harus diperhatikan agar perjanjian pemegang saham tersebut tidak mengakibatkan dampak yang merugikan terhadap stakeholder perusahaan yang lain.

Sebagai contoh adanya klausula tentang hak untuk menunjuk direktur, jangan sampai merugikan pemegang saham lain yang tidak menjadi pihak dalam perjanjian pemegang saham. Adanya ketentuan tentang hak untuk membubarkan perusahaan yang diberi kepada pemegang saham tertentu jangan sampai merugikan karyawan perusahaan, apabila dilaksanakan dengan tiba-tiba tanpa permberitahuan. Demikian pula, dalam penyusunan perjanjian pemegang saham perlu diperhatikan masalah kesetaraan dan keadilan yaitu : kesetaraan dan keadilan dalam memenuhi hak-hak stakeholder yang terdampak oleh perjanjian pemegang saham tersebut dan peraturan perundang-undangan yang berlaku. (RusmanSoleman (2013).

Sebagai contoh, pemberian hak membeli saham terlebih dahulu (right of first refusal) kepada pemegang saham tertentu jangan sampai merugikan hak pemegang saham lain yang tidak ikut serta dalam perjanjian pemegang saham. Pencantuman larangan kompetisi (covenant not to compete) yang dicantumkan di dalam perjanjian pemegang saham, jangan sampai melanggar ketentuan perundang-undangan tentang larang praktek monopoli dan menghalangi pemegang saham untuk mengembangkan bisnisnya di luar perusahaan.

\section{KESIMPULAN}

Pembahasan mengenai perjanjian pemegang saham yang diuraikan di atas adalah pembahasan umum, diperlukan pertimbangan yang cermat pada prinsipprinsip hukum yang mendasari ketentuan dan penyusunan yang diperlukan untuk membuatnya. Berdasarkan kebutuhan pemegang saham, perjanjian pemegang saham mungkin tidak membutuhkan masing-masing ketentuan khusus, mungkin pula diperlukan ketentuan tambahan, yang mungkin lebih sesuai untuk hukum yang mengatur selain dari undang-undang tentang perjanjian. Preferensi dan tujuan masing-masing pemegang saham dan setiap korporasi adalah berbeda, dan kehatihatian sangat diperlukan dalam merancang perjanjian pemegang saham untuk memastikan bahwa itu sesuai dengan maksud para pihak.

Meskipun perjanjian pemegang saham dibuat berdasarkan kebebasan berkontrak yang diakui secara hukum, namun penyusunan perjanjian pemegang saham di perusahaan, haruslah memperhatikan ketentuan peraturan perundangundangan yang berlaku, misalnya perundang-undangan tentang monopoli dan persaingan usaha, ketentuan tentang hak-hak intelektual, dan undang-undang lainnya. Demikian pula penyusunan perjanjian pemegang saham jangan sampai membawa dampak yang merugikan bagi pemangku kepentingan lainnya seperti, karyawan, customer, supplier dan juga pemerintah dan masyarakat yang terkait dengan kegiatan operasional perusahaan. 


\section{DAFTAR PUSTAKA}

Baglioni, Angelo (2011). Shareholders' agreements and voting power - evidence from Italian listed firms. Applied Economics, 2011, 43, 4043-4052.

Benedicte Millet-Reyes (2010). A Comparison Between One-Tier and Two-Tier Board Structures in France. Journal of International Financial Management and Accounting 21:32010.

Budiono, Herlin (2012). Arah Pengaturan Undang-Undang Nomor 40 Tahun 2007 Tentang Perseroan Terbatas Dalam Menghadapi Era Global. JurnalRechtsvinding, Media Pembinaan Hukum Nasional. Volume 1 Nomor 2, Agustus 2012.

CARVALHAL, Andre (2012). Do shareholder agreements affect market valuation? Evidence from Brazilian listedfirms. Journal of Corporate Finance, v. 18, p. 919-933, 2012.

Cheung, Rita (2012). Shareholders' agreements - shareholders' contractual freedom in company law. Journal of Business Law. J.B.L. 2012, 6, 504-530.

Crawford, W. W., \&Gratias, P. P. (1983). Shareholders' agreements a need for greater flexibility. Canadian Tax Journal, 31(2), 257-273.

Davies, Paul L. (2000). The Board of Directors: Composition, Structure, Duties and Powers. Company Law Reform in OECD Countries A Comparative Outlook of Current Trends. Stockholm, Sweden: OECD, 7-8 December 2000.

EcoDaa.s.b.l. (2014). Directors' Note One-Tier Versus Two-Tier Board System. September 2014.

Ghezzi, F., and Malberti, C. (2008). The Two-Tier Model and the One-Tier Model of Corporate Governance in the Italian Reform of Corporate Law. European Company and Financial Law Review, 5(1), 1-47.

Jouber, Habib (2021). Is the effect of board diversity on CSR diverse? New insights from one-tier vs two-tier corporate board models. CORPORATE GOVERNANCE. VOL. 21 NO. 1 2021, pp. 23-61.

Keay, Andrew (2019). Having Regard for Stakeholders in Practising Enlightened Shareholder Value. Oxford University Commonwealth Law Journal 2019, Vol. 19, No. 1, 118-138.

Kulms, Rainer (2001). A Shareholder's Freedom of Contract in Close Corporations Shareholder Agreements in the USA and Germany. European Business Organization Law Review 2: 685-701. 
Office of the Director of Corporate Enforcement (2015): The Principal Duties and Power of Members and Shareholders Under the Companies Act.

Soleman, Rusman (2013). PengaruhPengendalian Internal Dan Good Corporate Governance TerhadapPencegahan Fraud. JAAI Volume 17 No.1. Juni 2013: 57-74

Suwarsono Muhammad dan Andi Yuliansyah. Implikasi Perubahan Lingkungan Bisnis Terhadap Strategi Perusahaan, StudiKasus: Pt Bogasari Flour Mills. JurnalSiasatBisnis Vol. 12 No. 3, Desember 2008 Hal: 219-240.

Watson, Alan (1974). Legal Transplants: An Approach to Comparative Law. 2nd ed. 1993, 1st ed. 1974. Athens, Georgia: University of Georgia Press.

Williams, Cynthia A. (2016) Corporate Social Responsibility and Corporate Governance. Articles \& Book Chapters. Paper 1784.http://digitalcommons.osgoode.yorku.ca/scholarlyworks/1784.

Wirawan, Bayu (2014). Kepemilikan Keluarga, Hubungan Politik Dan Family Aligned Board TerhadapImplementasi Tata Kelola Perusahaan. JAAI Volume 18 Nomor 2. Desember 2014. 139-155.

Reardon, Dennis C. (2019). When It's Time to Add a Shareholder. JOURNAL OF FINANCIAL SERVICE PROFESSIONALS | MAY 2019.

Silva, Andre Leonardo Pruner da; Lana, Jeferson; Marcon, Rosilene Agreeing and Impacting: The Effect of the Shareholders' Agreement on Firms' Market Value BBR. Brazilian Business Review, vol. 15, no. 1, 2018, January-February, pp. 88-104.

Soleimani,Abrahim, Schneper William D. and Newburry, William (2014). The Impact of Stakeholder Power on Corporate Reputation: A Cross-Country Corporate Governance Perspective. Organization Science, July-August 2014, Vol. 25, No. 4 (July-August 2014), pp. 991-1008.

TareqNa'el Al-Tawil (2018). Shareholders' agreements and their enforceability in the UAE. J.B.L. 2018, 8, 652-662.

The Corporation Law Committee of the Association of the Bar of the City of New York (2010). The Enforceability and Effectiveness of Typical Shareholders Agreement Provisions. The Business Lawyer, August 2010, Vol. 65, No. 4 (August 2010), pp. 1153-1203. 
AKSARA: Jurnal Ilmu Pendidikan Nonformal

P-ISSN 2407-8018 E-ISSN 2721-7310 DOI prefix 10.37905

Volume 07, Issue 03 September 2021

http://ejurnal.pps.ung.ac.id/index.php/Aksara 